\title{
Increasing Efficiency: Case Study of Ready Made Garments in Bangladesh
}

\author{
${ }^{1}$ Mr. Mohammad Alam Tareque*, ${ }^{2}$ Nazrul Islam, ${ }^{3}$ Shuvashish Roy \\ ${ }^{1}$ Bangladesh University of Professionals, Faculty of Business Studies, Mirpur Cantonment, Dhaka- 1216, \\ Bangladesh \\ ${ }^{2}$ Canadian University of Bangladesh, Banani Dhaka-1213, Bangladesh, \\ 3The University of Burdwan, Rajbati, Bardhaman - 713 104, West Bengal, India,
}

\begin{abstract}
:
In this article, we look at recent developments in the Bangladesh garment industry on the issue of efficiency and productivity. First, we were looking for new ideas. How are companies trying to improve their efficiency? Then, we were trying to see if there was a relationship between a companies' (x) efficiency and cost saving (a) and increased revenue (y). Of course, intuitively, we would all hypothesise that there must be some relationship between efficiency and reduction of cost of manufacturing and ultimately increased revenue. Further, we would all probably hypothesise that the slope of the function describing that relationship must be significantly higher than zero. Nevertheless, we tried to document the connection so that companies can believe it and give it more attention. Theoretical relationships are one of the weakest ways to try to persuade CEOs of the existence of anything. Show them the numbers, only then they will agree. This paper is an attempt to persuade a readymade garments manufacturing unit to increase efficiency to cut cost and increase revenue, we show that there is a direct causal relation to efficiency and revenue earnings.
\end{abstract}

Keywords: Efficiency, Cost Reduction, Competitive Advantage, Bangladesh Ready Made Garments.

\section{Introduction}

Today's manufacturing industries are operating in a new paradigm of volatility, uncertainty, complexity (chaotic), and ambiguity, known as VUCA atmosphere. Therefore, to save operational costs, most industrialists will try to maximise efficiency. This means bulk production of standardised products, reduced workforce and shorter lead time where they need to be more efficient, effective and provide variety of good quality products at lower prices. This is a difficult goal to achieve since good quality products are associated with rise of operational costs.

Ready Made Garments (RMG) of Bangladesh (BD) is troubled with poor efficiency. The efficiency of RMG BD is an average of $45 \%$ comparing to its competitors who fair an average of more than $65 \%$. Lack of efficiency leads to increased lead time which is 45 days to 90 days for RMG BD. Lack of efficiency not only results to increased lead time but also cost money and therefore, RMG BD has a higher cost of manufacturing despite having the advantage of the world's cheapest labour.

This is an attempt to address issues that affects efficiency by increasing attributes that compliment and by minimising factors that inhibit efficiency. We quantify the factors having direct impact on efficiency and measure ways to increase the impact. Finally, we genaralised the quantification of our measures for readymade garments.

\section{The Research Problem}

Efficiency is an important attribute because inputs are scarce and it cost money. Therefore, it is essential for any organisation to achieve their targeted productivity by using limited resources like operators (men/women), materials, machines, money and time. Because of poor sewing efficiency, XYZ (not original Name) Knitting (Pvt.) 
Ltd.'s cost of manufacturing is higher comparing other manufacturing units in the RMG BD. The reason is they failed to achieve their daily targets and also daily sewing efficiency level which has a direct effect on revenue earnings.

\subsection{Research Question}

What are the relationship between Efficiency, Cost, and Revenue in the RMG BD?

\section{Literature Review}

\section{What is efficiency?}

The ratio of the useful work (output) performed by a man, machine or in a process to the total input taken in.

\section{Productivity}

Productivity is the measure of output per unit of input.

\section{Workstation}

An ideal workstation in the apparel industry is a machine layout which consist of minimum motion, travel, waiting (least movements and minimum length of every action) and ergonomically comfortable. A machine workstation looks like following:

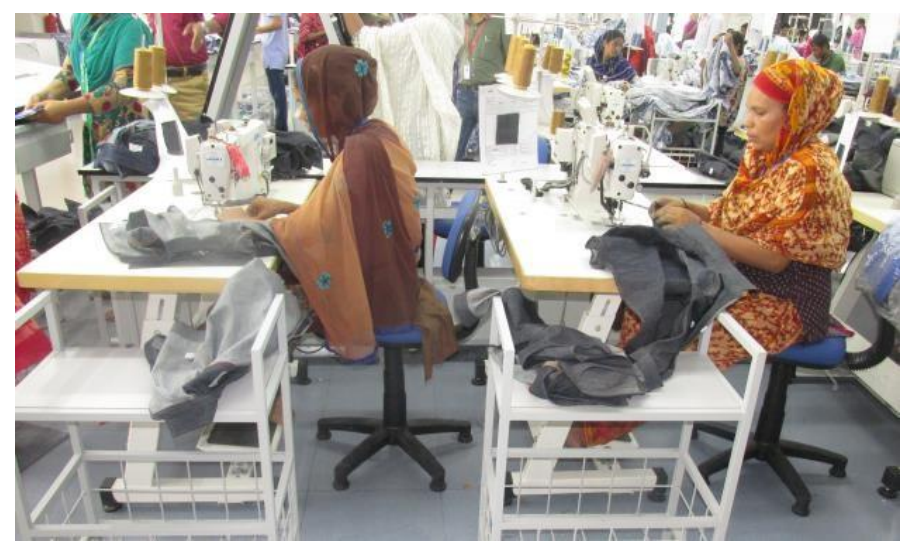

\section{Line Layout}

Figure 1: Workstation

The sewing line layout is a sequential formation where sewing workstations are placed on the sewing floor to produce an output. Materials start flowing from the back to the front in a straight single line layout. There are modular line layouts, and $U$ shaped line layout or Section layouts, too. Some also use circular and zigzag shaped layout. One directional linear single line layout is as follows:

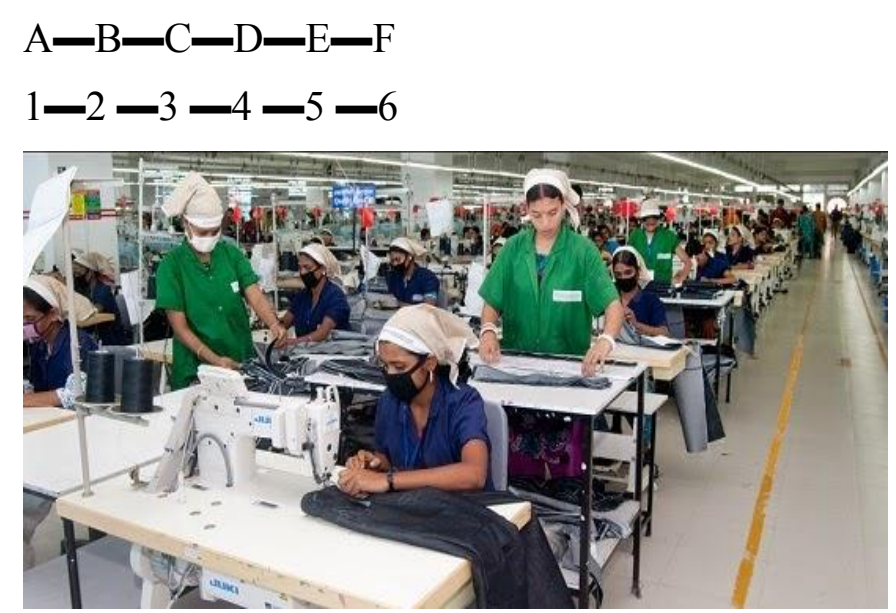

Workstation and line layout

\section{Pic: Denim Experts Bangladesh}

\section{Bottleneck in Production Line}

In a production sewing line, where input flow is not flowing smoothly, and production goes under capacity. Meaning input-capacity-flow-output is not balanced or one part is performing below. In other words a piled up WIP -work in process is the sign of a bottleneck. The following diagram shows bold marks are bottlenecks.
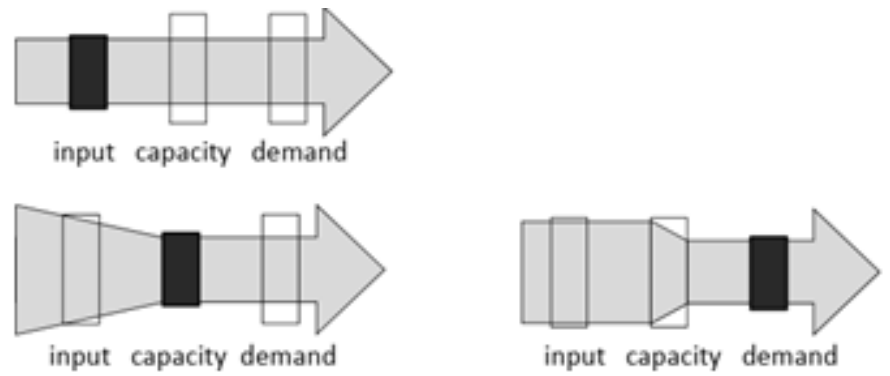

\section{Figure 2: Bottleneck}

\section{Line Balancing}

In a balanced line, input will flow smoothly and no time will be lost in waiting for work. Balancing the line means jobs assigned to the workstations in a way that there is no piled up work/input in one workstation and other workstation is waiting for work, so each workstation has input, WIP according to workstation cycle time, and idle time across all workstations are minimized. Simply stating minimising the bottlenecks will make a line balanced.

\section{Standard Minute Value (SMV)}

Standard Time (also referred to as the "Standard Minute Value" or "SMV"), is the time required for a qualified worker working at "Standard 
Performance" to perform a given task. The SMV includes additional allowances for Rest and Relaxation, Machine Delay and anticipated Contingencies

\section{Multi-skilled operators}

Operators who can perform multiple sewing operations and can work in a major process like bartack, overlock, kansai, flatlock machines etc.

\section{Factors Affecting Efficiency}

Following are the factors considered to increase efficiency:

1) Good Leadership

2) Automation.

3) Layout to reduce SMV

4) Assign multi-skilled operators to do multiple operations

5) Incentive for high performance to reduce OT

6) Right first time quality-no rework.

7) PO wise batch wise size wise output.

8) Reduce and have required Work In Process WIP.

9) Reduce or eliminate Non Productive Time NPT.

10) Operators' skill development through training.

On the other hand, followings are factors that inhibit sewing efficiency:

1) Poor Leadership

2) Operator Working Skills

3) Working Experience

4) Job satisfaction

5) Machine Breakdown

6) Assigned Quality Targets

7) Physical Working Environment

8) Training and Development

9) Supply Chain Problem and Material Quality

10) Change Over time

\section{Automation}

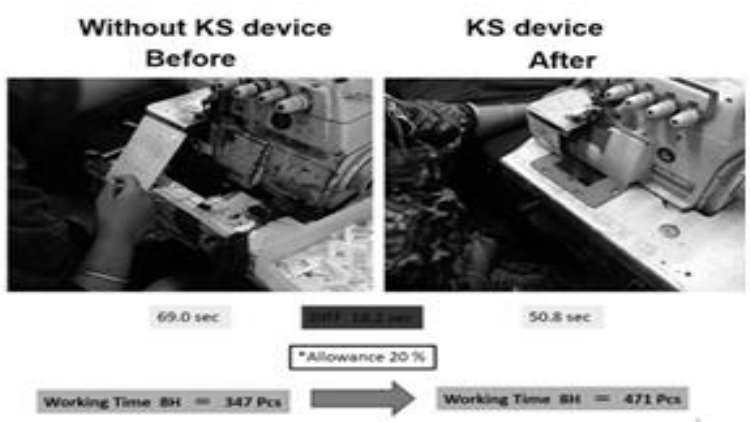

An overlock machine with $\mathrm{KS}$ attachment saves 18.2 seconds in each cycle time of operation. Therefore, 200 pieces per hour would see a savings of ( $200 \times 18.2$ X $60 \times 60$ seconds) 3,640 minutes = 60 hour, that's 2 and a half day. The automation and use of folders will reduce the SMV, too.
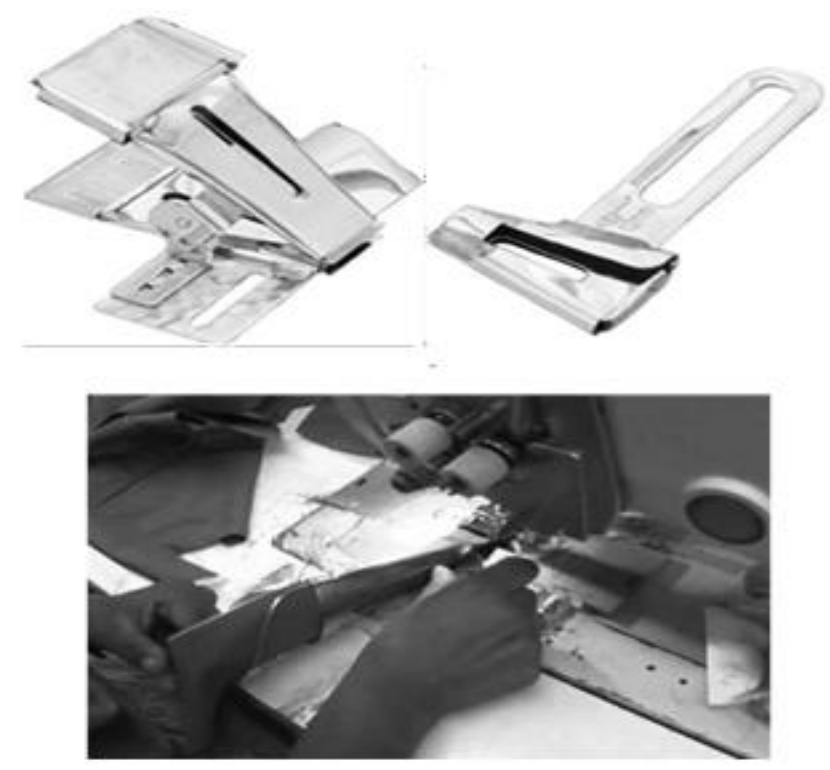

Fig 4: Folders

Along with folders to minimise cycle time and reduce SMV we can use auto trimmers and other automation to reduce work cycle time.

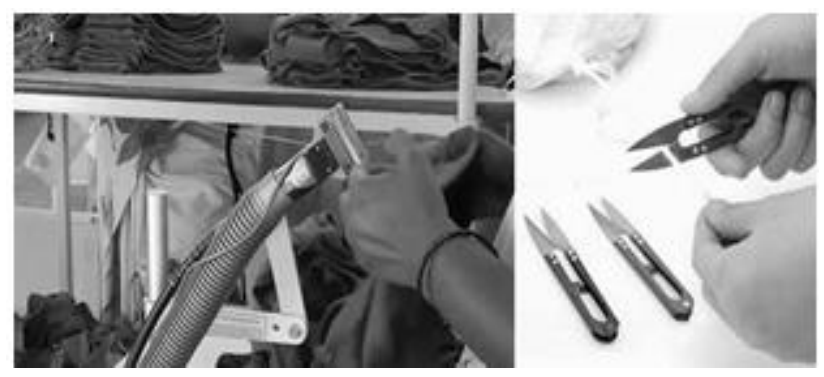

Fig 5: Manual vs Automatic thread trimming

\section{Line Layout}

One direction sewing machine single layout

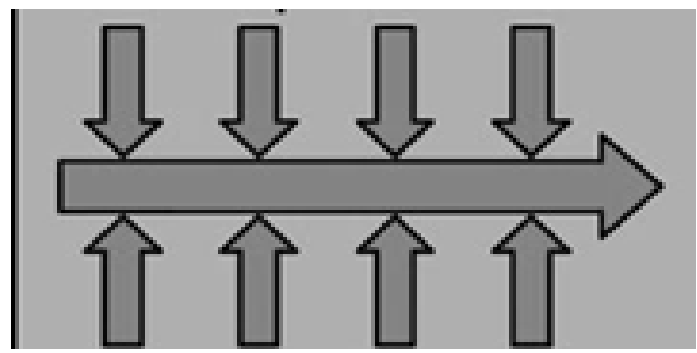

Figure 6.1: Single Line

Fig 3: Automation with an attachment/device 
After observing the motion study the work study team has to find out the bottleneck and put machines or men to address the bottleneck. This layout can be modified as below

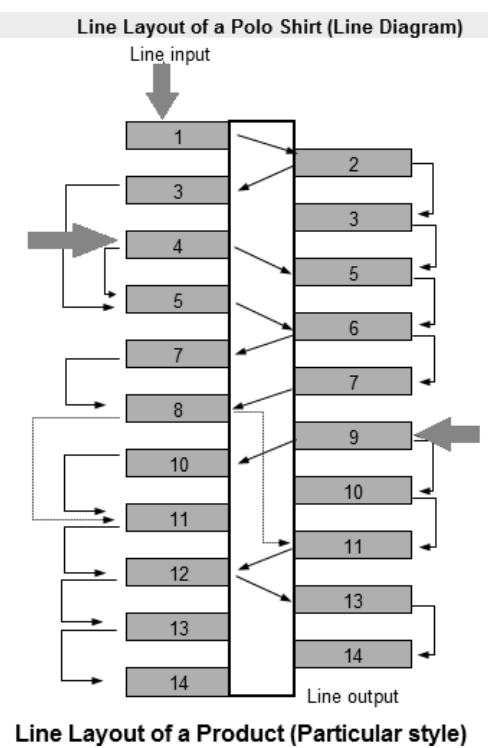

Figure 6.2: Modified Line Layout

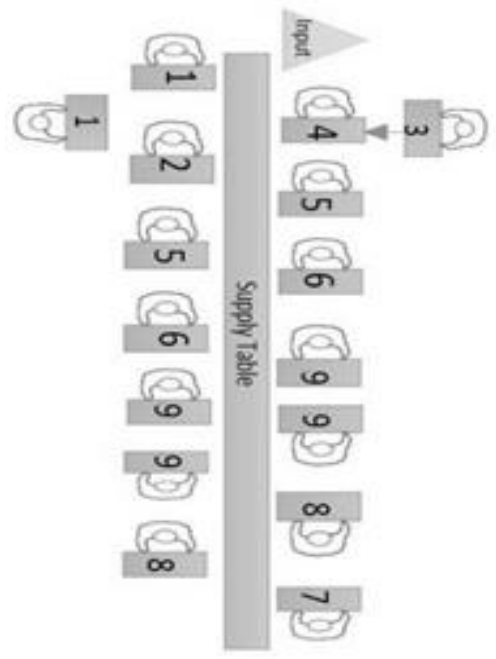

Fig 6.3: Modified Line Layout

\section{Layout Assigning Multi Skilled Operators}

The layout depends on the space of the factory, the number of multi skilled operator available, and depends on the single piece flow approach or batch system flow approach. In all cases the objective will be to reduce motion, reduce waste, and reduce travel time and Work In Progress (WIP). Multi skilled operators work in a $\mathrm{U}$ layout as below, and reduce men, machine by doing multiple operations. Below dotted lines show multiple operations in a $U$ shaped layout:

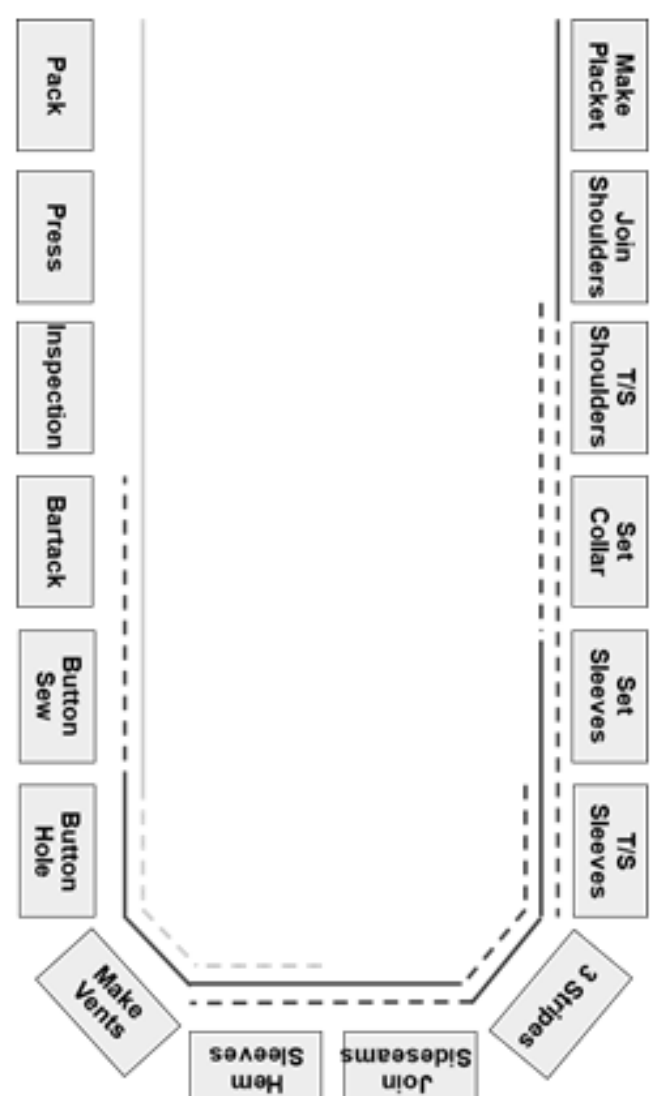

Fig 7: Layout of Multiple Operations

This layout is the most suitable, productive and cost effective layout which enables multi-skilled operators to work up to $65 \%$ of their efficiency (average efficiency of Bangladesh RMG operators are $45 \%$ )

If the factory is running same product family in the lines then these are adaptive lines, we may also use flexible lines for product families that are same type-body and same SMV, may be the colour will be different. However, the zero changeover time has to be implemented to derive maximum efficiency.

\section{Incentive for high performance to reduce Over Time (OT)}

In Bangladesh RMG, the cost of making a Polo tee shirt is plus-minus $3 \$$ where the operators and workers work generally 10 hour, 8 hour work shift and 2 Hour OT.

An OT is double payment per hour than the general hours. If a worker works 2 hour per day then his/her total OT per month will be 48 hours ( 2 hour $\mathrm{x} 6$ days $\mathrm{x} 4$ weeks), however the country's compliance audit reports show 68, even some cases 70 hours of OT. Again, any holiday work has to be compensated by 
an off day in addition to OT, making it almost $4 \mathrm{X}$ times than the general pay. Therefore, any incentive to minimise OT will be profitable for the factory. Any amount of OT will make the cost of manufacturing higher.

\section{Man Machine Ratio- MMR}

In RMG BD the operators, helpers, and iron men are the direct manpower, the notion is anybody behind the needle is direct manpower and adds value. The indirect manpower are: quality checkers, finishing men, industrial engineers, and non-value added manpower are: securities, administrative personnel etc. So to keep the MMR cost effective we look at a man machine ratio of $1: 1.8$. Here also automations can reduce manpower. For example, physical securities can be replaced by CCTV cameras and monitored from a single monitoring room. RFID tags may be used to make store inventory and reduce store manpower.

\section{Right first time quality-no rework}

RMG BD works in an accepted quality level method (AQL) however, any quality defect has direct impact and needs to do rework which increases cost of manufacturing. Not only it cost money, it cost time, it cost material and even failure to ship goods for not meeting required quantity.

\section{PO wise batch wise size wise output}

RMG products are normally orderd size wise and purchase ordesr include size wise ratio, therefore if the input is given likewise then we do not lose time to compile and close orders PO wise.

\section{Work In Process -WIP}

Adequate WIP is the pre-requisite to have targeted output, generally the WIP is to be one day production, and the flow will be one day production out and one day production in-and one day as WIP

\section{Non Productive Time -NPT}

Followings ate the probale reasons that we have non- productive times NPTs:

\section{Meetings}

Compliance meetings HR Meetings Production Meetings Fire Drills

Trainings marketing issues

Merchandising issues Cutting delay - input delay Print delay
Embroidery delay Fabric delay

Reworks

Machine breakdown Power failure

Operators' skill development through training

All operators' skill assessment done and a register maintained. Apprentices receive special training. Operators with single skill are trained to become multi- skilled operators. Critical and non-critical operations are segregated to train better. Appropriate skill level required to perform an operation is measured. Machine used are: Single Needle Lock Stitch, over edge, semi-automatic machine or Flat Lock machine. Moreover, operators are trained to handle little break down of machines. Specialised, suitably trained instructors are to impart and conduct training. Training shall have initial training area before they are put into the lines.

\section{Poor Leadership}

Opposite of the warmth of good leadership any organisation can feel the grunt of poor leadership who fails to plan properly and therefore, the implement becomes difficult and costly.

Operator Work Skills, Training and Development, Work Experience, Job satisfaction, Physical Working Environment, Assigned Quality Targets all these factors are interrelated. Likewise Machine Breakdown, Supply Chain Problem and Material Quality all are inter related factors that affect the efficiency.

\section{Changeover time}

Changeover time in sewing line is the time taken from producing the last piece of the completing style to the time taken in producing the first piece for the new style with good qualities.

Changeover Time=Time of first good quality piece for the new style - Time of last good quality piece of the completing style

Putting a product family in one line will ensure reduced change over time.

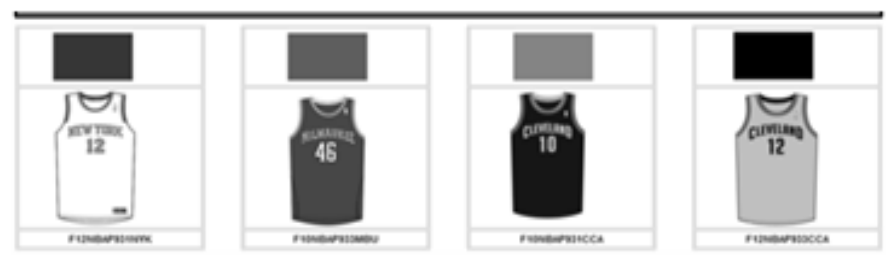


Flexible Cell design will also reduce change over time.

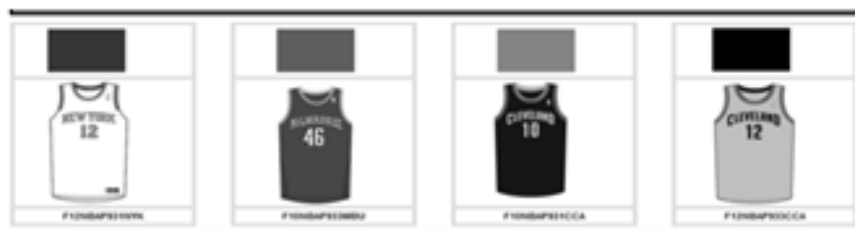

Data showing reduced change over monitoring
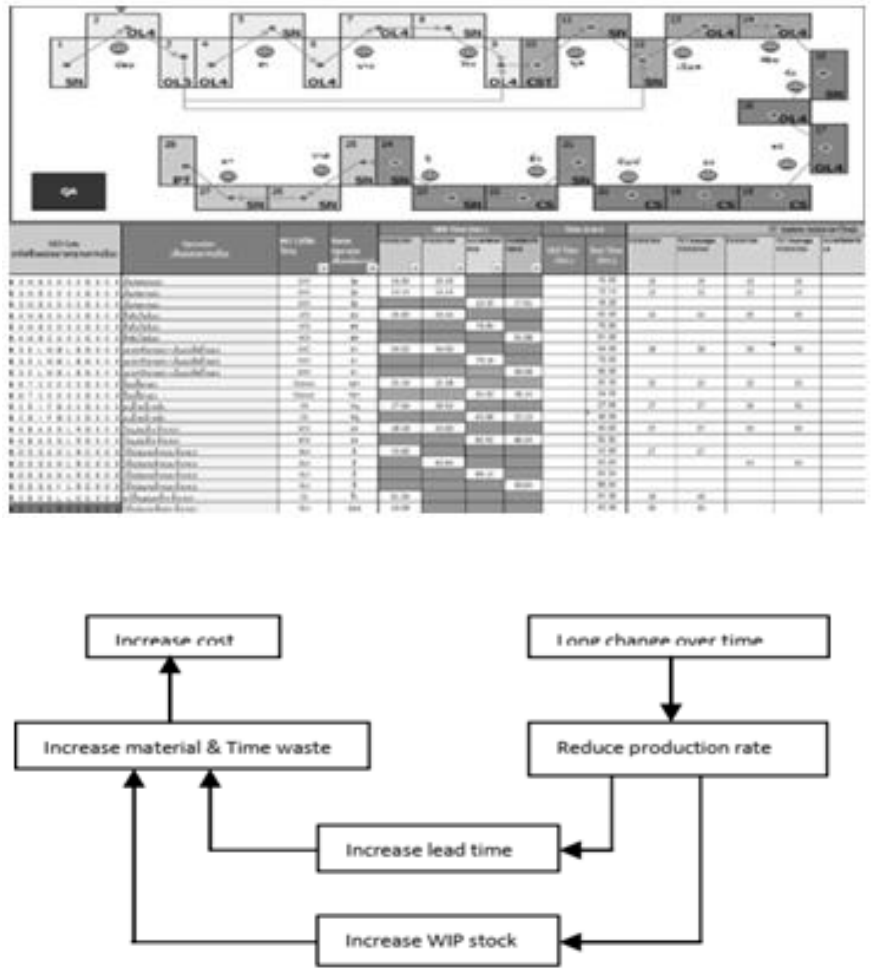

Fig8 3: figures showing impact of change over time



Fig 9: Cell approach reduced change over or zero time 


\section{Methodology}

The conceptual framework for the statistical analysis of increasing efficiency in the readymade garments in Bangladesh

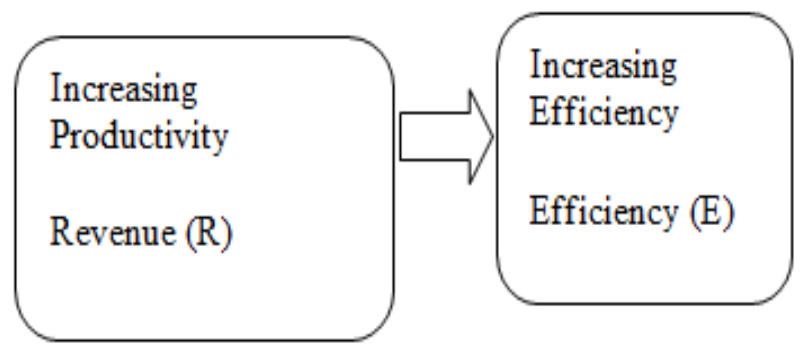

Fig 14: Concept for Statistical Analysis

\begin{tabular}{|l|l|}
\hline Increasing Productivity & Increa sing Efficiency \\
- Revenue (R) & . Efficiency (E) \\
& ManufacturingCost \\
&
\end{tabular}

The statistical process involved in the study is multiple regression analysis using all the two productivity related factors of readymade garments factories, as considered in the study, as the predictor variables and one effects of efficiency as response variable individually. Thus, the regression equation has been attempted to be constructed as under:

Productivity related factors in the readymade garments factories $=\mathrm{f}[$ Revenue $(\mathrm{R})$, Manufacturing Cost (MC)]

i.e. Productivity related factors in the readymade garments factories $=\alpha+\beta 1 * \mathrm{R}+\beta 2 * \mathrm{MC}$

The values of the predictor and respondent variables were on ordinal scale. For constructing the regression equation we have used ordinal data.

The efficiency of the regression equation has been tested on the basis of the following parameters:

a. Adjusted R2

b. Statistical significance of the F-statistic of ANOVA tested at 5\% Level of Significance

c. Statistical significance of the t-statistic of the regression coefficients of each of the predictor variables tested at 5\% Level of Significance

d. Durbin-Watson statistic for checking the problem of autocorrelation, if any e. Variance Inflation factor (VIF) of each of the predictor variables to test any probable problem of multicollinearity.

The dependent variable i.e. Efficiency (E) has been regressed using all the 2 predictor variables i.e. $\mathrm{R}$ and MC simultaneously.

While constructing the regression equation, the coefficients of the predictor variables have been tested for their statistical significance by framing the following hypotheses:

H0: The coefficient of the predictor variable is not statistically significant

H1: The coefficient of the predictor variable is not statistically significant

The predictor variables having statistically insignificant coefficients i.e. the absolute value of tstatistic for which is less than 2 and the p-value is less than or equal to 0.05 , have been rejected and the regression equation has again been constructed with the statistically significant predictor variables only.

The robustness of the final regression equation thus formed for the dependent variable, has been tested by framing the following hypotheses:

H0: The regression equation is not statistically robust $\mathrm{H} 1$ : The regression equation is statistically robust

The null hypotheses is rejected at al p-values of less than 0.05 .

The regression equation has considered to be free from the problem of autocorrelation if the DurbinWatson statistic has been found to lie between 1.20 to 2.10 .

The regression equation has been considered to be free from the effects of multicollinearity if the values of the VIF (Variance Inflation Factor) statistic of the predictor variables in the final regression equation have been found to be below 10.00 .

Ultimately, the distribution of the residuals of the regression equation has been tested whether they follow a normal distribution. The greater degree of conformity of the distribution of residuals bear to a normal distribution, the more robust the regression equation is deemed to be. 


\section{Results}

From the above research we found, Net FOB Cost is to

$28.25($ from $28.97 \$)=.72 \$$ reduced per dozen i.e. $.06 \$$ per piece.

Cost of making is reduced to $3.55 \$$ (from $4.20 \$$ ) $=$ $.65 \$$ So per piece cost is reduced by $.65 / 12=.054 \$$

If we have 50,000 pcs orders per PO (purchase orders) then 5 POs will have 250,000 pcs tee shirt, i.e we are able to reduce $13,500 \$$ (reduction in cost of making), and $15,000 \$$ reduction in FOB cost. Let us see how by explaining factors one by one:

Modification of processes, decreased SMV reduce the Cost of Manufacturing

\begin{tabular}{|c|c|c|c|}
\hline 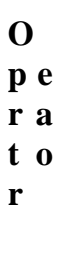 & Operation & SMV & Product \\
\hline 1 & Hem & 0.98 & \\
\hline 2 & Attach Placket & 0.15 & \\
\hline 3 & Make Placket & 1.58 & \\
\hline 4 & Join Shoulders & 0.38 & \\
\hline 5 & T/S Shoulders & 0.36 & \\
\hline 6 & Set Collar & 0.98 & \\
\hline 7 & Set Sleeves & 0.78 & \\
\hline 8 & $\mathrm{~T} / \mathrm{S}$ Sleeves & 0.72 & \\
\hline 9 & Join Side seams & 0.57 & \\
\hline $\begin{array}{l}1 \\
0\end{array}$ & Hem Sleeves & 0.25 & \\
\hline $\begin{array}{l}1 \\
1\end{array}$ & Make Vents & 1.13 & \\
\hline $\begin{array}{l}1 \\
2\end{array}$ & $\begin{array}{l}\text { Buttonhole/Butt } \\
\text { o n sew }\end{array}$ & 0.60 & \\
\hline $\begin{array}{l}1 \\
3 \\
\end{array}$ & Bartack & 0.58 & \\
\hline $\begin{array}{l}1 \\
4 \\
\end{array}$ & Inspect & 0.98 & \\
\hline $\begin{array}{l}1 \\
5 \\
\end{array}$ & Press & 0.58 & \\
\hline \multirow[t]{2}{*}{$\begin{array}{l}1 \\
6 \\
\end{array}$} & Pack & 0.38 & \\
\hline & Total & 11.68 & \\
\hline
\end{tabular}

Table 1: Calculating SMV of a tee shirt
Cost Sheet of manufacturing as per SMV 11.68

\begin{tabular}{|c|c|c|c|c|}
\hline \multicolumn{2}{|c|}{ CM CALCULATION } & \multirow{2}{*}{\multicolumn{3}{|c|}{$\begin{array}{c}\text { Sales Contract } 0001 \\
\text { XYZ KNITTING LTD }\end{array}$}} \\
\hline \multicolumn{2}{|l|}{ Factory/Unit } & & & \\
\hline SMV & 11.68 & & & \\
\hline \multicolumn{2}{|c|}{ Number of Machines per Line } & & & 19 \\
\hline \multicolumn{2}{|c|}{ Factory cost per machine/line } & & Tk. & 1400 \\
\hline \multicolumn{3}{|c|}{ Production per line per day (10 hrs) } & Pcs & 2000 \\
\hline \multicolumn{2}{|c|}{$\begin{array}{l}\text { Production cost per dozen in } \\
\text { taka }\end{array}$} & & Tk. & 160 \\
\hline \multicolumn{3}{|c|}{ Production cost in DznUS $\$(\$=$ Tk. 78) } & USD & 4.20 \\
\hline \multicolumn{5}{|l|}{ A. Material Cost } \\
\hline \multicolumn{2}{|l|}{ Particulars } & & & \\
\hline \multicolumn{2}{|c|}{ 1. Fabric Cost with comm } & $\$ 12.97$ & & \\
\hline \multicolumn{2}{|c|}{ 2. Accessories with comm } & $\$ 6.22$ & & \\
\hline \multicolumn{2}{|l|}{ Total Material Cost } & $\$ 19.19$ & & \\
\hline \multicolumn{5}{|l|}{ B. Production Cost } \\
\hline \multicolumn{5}{|l|}{ Particulars } \\
\hline \multicolumn{2}{|l|}{ 1. Factory cost } & $\$ 4.20$ & & \\
\hline \multicolumn{2}{|l|}{ 2. Washing Cost } & $\$ 1.00$ & & \\
\hline \multicolumn{2}{|c|}{ 3. Garment/Over Dyeing } & $\$ 0.00$ & & \\
\hline \multicolumn{2}{|l|}{ 4. Dry Processing } & $\$ 0.00$ & & \\
\hline \multicolumn{2}{|l|}{ 5. Printing } & $\$ 2.00$ & & \\
\hline \multicolumn{2}{|l|}{ 6. Embroidery } & $\$ 0.00$ & & \\
\hline \multicolumn{2}{|l|}{ 7. Others (if any) } & $\$ 0.00$ & & \\
\hline \multicolumn{2}{|c|}{ Total Production Cost } & $\$ 7.20$ & & \\
\hline \multicolumn{5}{|l|}{ C. Cost of Goods } \\
\hline \multicolumn{5}{|l|}{ Particulars } \\
\hline \multicolumn{2}{|c|}{ Cost of Goods Sold $(\mathrm{A}+\mathrm{B})$} & $\$ 26.40$ & & \\
\hline \multicolumn{5}{|l|}{ D. Overhead } \\
\hline \multicolumn{5}{|l|}{ Particulars } \\
\hline 1. $\mathrm{HO} \& \operatorname{Admin} \mathrm{C}$ & & $\$ 0.13$ & & \\
\hline $\begin{array}{l}\text { 2. Merchandising } \\
\text { Cost }\end{array}$ & \& Mktg & $\$ 0.13$ & & \\
\hline 3. Test \& Courier & & $\$ 0.66$ & & \\
\hline $\begin{array}{l}\text { 4.Export } \\
\text { commercial/finance }\end{array}$ & & $\$ 0.26$ & & \\
\hline 5. Others(if any) & & & & \\
\hline Total Overhead & & $\$ 1.19$ & & \\
\hline & & & & \\
\hline
\end{tabular}




\begin{tabular}{|l|l|l|l|l|}
\hline \multicolumn{2}{|l|}{ E. Final Cost of Goods } & & & \\
\hline Particulars & & & & \\
\hline \multicolumn{2}{|l|}{ Final Cost of Goods } & $\$ 27.59$ & & \\
\hline F. Corporate Profit & & & & \\
\hline Particulars & & & \\
\hline Corporate Profit (5\%) & $\$ 1.38$ & & \\
\hline G. Net FOB Cost & & & & \\
\hline Particulars & & & & \\
\hline NET FOB COST & & $\$ 28.97$ & & \\
\hline H. Calculated CM & & & & \\
\hline Particulars & & & & \\
\hline Calculated CM & $\$ 6.77$ & & \\
\hline ACTUAL CM & $\$ 7.21$ & & \\
\hline \multicolumn{2}{|l|}{ Factory CM } & & & \\
\hline Corporate CM & & $\underline{\$ 7.71}$ & \\
\hline Actual CM & & $\$ 7.21$ & \\
\hline
\end{tabular}

Table 2: Cost sheet

Reducing SMV after modification by industrial engineering as follows:

\begin{tabular}{|c|c|c|c|}
\hline $\mathbf{p}^{\mathbf{O}}$ & Operation & $\mathbf{V}^{\text {SM }}$ & $\begin{array}{c}\text { After } \\
\text { Modification }\end{array}$ \\
\hline 1 & Hem & $8^{0.9}$ & $\begin{array}{l}\text { Operation } \\
\text { minimised }\end{array}$ \\
\hline 2 & Attach Placket & $5^{0.1}$ & $\begin{array}{l}\text { Operation } \\
\text { minimised }\end{array}$ \\
\hline 3 & Make Placket & $8^{1.5}$ & 1.58 \\
\hline 4 & Join Shoulders & $8^{0.3}$ & 0.38 \\
\hline 5 & T/S Shoulders & $6^{0.3}$ & 0.36 \\
\hline 6 & Set Collar & $8^{0.9}$ & 0.98 \\
\hline 7 & Set Sleeves & $8^{0.7}$ & 0.78 \\
\hline 8 & $\mathrm{~T} / \mathrm{S}$ Sleeves & $2^{0.7}$ & 0.72 \\
\hline $0^{1}$ & Join Sideseams & $7^{0.5}$ & 0.57 \\
\hline $1^{1}$ & Hem Sleeves & $5^{0.2}$ & 0.25 \\
\hline
\end{tabular}

\begin{tabular}{|c|c|c|c|}
\hline $2^{1}$ & Make Vents & $3^{1.1}$ & 1.13 \\
\hline $3^{1}$ & $\begin{aligned} & \text { Buttonhole/Buttons } \\
\text { ew } & \end{aligned}$ & 0.6 & 0.6 \\
\hline $4^{1}$ & Bartack & $8^{0.5}$ & 0.58 \\
\hline $5^{1}$ & Inspect & $8^{0.9}$ & 0.98 \\
\hline $6^{1}$ & Press & $8^{0.5}$ & 0.58 \\
\hline \multirow[t]{2}{*}{$7^{1}$} & Pack & $8^{0.3}$ & 0.38 \\
\hline & Total & $68^{11 .}$ & 9.87 \\
\hline
\end{tabular}

Table 3: SMV Reduced by modification

SMV reduced by: $11.68-9.87=1.81$ minutes

\begin{tabular}{|c|c|c|c|c|}
\hline \multicolumn{2}{|c|}{ CM CALCULATION } & \multirow{2}{*}{\multicolumn{3}{|c|}{$\begin{array}{c}\text { Sales Contrac-06 } \\
\text { XYZ KNITTING LTD }\end{array}$}} \\
\hline \multicolumn{2}{|l|}{ Factory/Unit } & & & \\
\hline SMV & 9.87 & & & \\
\hline \multicolumn{2}{|c|}{ Number of Machines per Line } & & & 17 \\
\hline \multicolumn{2}{|c|}{ Factory cost per machine/line } & & Tk. & 1400 \\
\hline \multicolumn{3}{|c|}{ Production per line per day (10 hrs) } & Pcs & 2000 \\
\hline \multicolumn{2}{|c|}{$\begin{array}{l}\text { Production cost per dozen in } \\
\text { taka }\end{array}$} & & Tk. & 143 \\
\hline \multicolumn{3}{|c|}{ Production cost in Dzn US $\$(\$=$ Tk. 78) } & USD & 3.55 \\
\hline \multicolumn{5}{|l|}{ A. Material Cost } \\
\hline \multicolumn{5}{|l|}{ Particulars } \\
\hline \multicolumn{2}{|c|}{ 1. Fabric Cost with comm } & $\$ 12.97$ & & \\
\hline \multicolumn{2}{|c|}{ 2. Accessories with comm } & $\$ 6.22$ & & \\
\hline \multicolumn{2}{|c|}{ Total Material Cost } & $\$ 19.19$ & & \\
\hline \multicolumn{5}{|l|}{ B. Production Cost } \\
\hline \multicolumn{5}{|l|}{ Particulars } \\
\hline \multicolumn{2}{|l|}{ 1. Factory cost } & $\$ 3.55$ & & \\
\hline \multicolumn{2}{|l|}{ 2. Washing Cost } & $\$ 1.00$ & & \\
\hline \multicolumn{2}{|c|}{ 3. Garment/Over Dyeing } & $\$ 0.00$ & & \\
\hline \multicolumn{2}{|l|}{ 4. Dry Processing } & $\$ 0.00$ & & \\
\hline \multicolumn{2}{|l|}{ 5. Printing } & $\$ 2.00$ & & \\
\hline \multicolumn{2}{|l|}{ 6. Embroidery } & $\$ 0.00$ & & \\
\hline \multicolumn{2}{|l|}{ 7. Others (if any) } & $\$ 0.00$ & & \\
\hline \multicolumn{2}{|c|}{ Total Production Cost } & $\$ 6.55$ & & \\
\hline
\end{tabular}




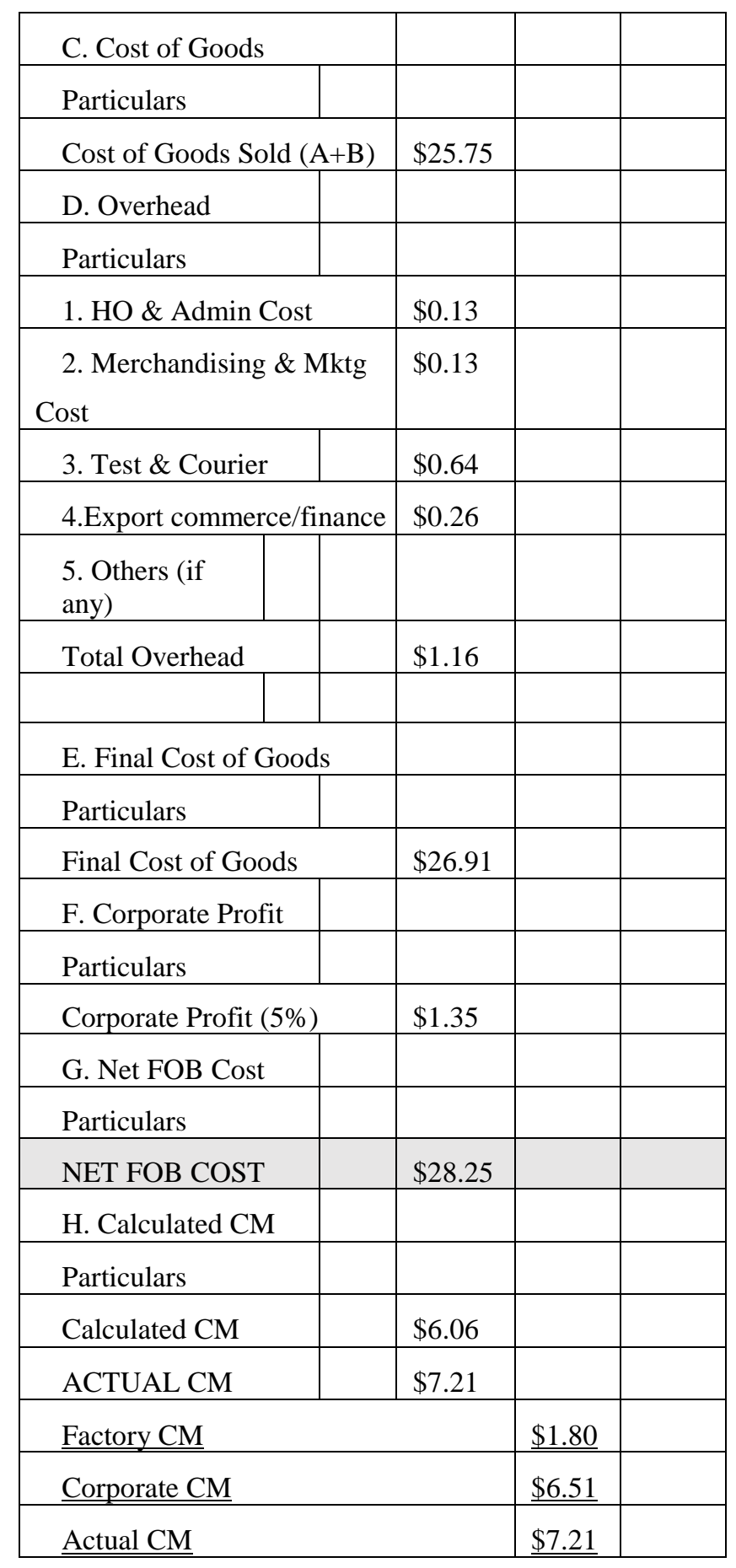

Modified Operation Bulletin to decrease men and machine as per revised cost and SMV

\begin{tabular}{|c|l|c|r|}
\hline N & \multirow{2}{*}{ OPERATION } & M/C & SMV \\
\hline O & $\begin{array}{l}\text { CARE LABEL } \\
\text { ATTACH }\end{array}$ & SNL & 0.12 \\
\hline 2 & PLACKET ATTACH & MNL & 0.25 \\
\hline
\end{tabular}

Table 4: Revised cost as per reduced SMV

\begin{tabular}{|c|c|c|c|}
\hline & POSITION MARK & & \\
\hline \multirow[t]{2}{*}{3} & $\begin{array}{l}\text { PLACKET } \\
\text { ROLLING \& }\end{array}$ & \multirow[t]{2}{*}{ SNL } & \multirow[t]{2}{*}{0.32} \\
\hline & MARK & & \\
\hline 4 & PLACKET ATTACH & SNL & 0.4 \\
\hline 5 & $\begin{array}{l}\text { PLACKET CUT \& } \\
\text { NOSE TK }\end{array}$ & SNL & 0.27 \\
\hline \multirow{2}{*}{6} & $\begin{array}{l}\text { FRONT \& BACK } \\
\text { PART }\end{array}$ & \multirow{2}{*}{ MNL } & \multirow{2}{*}{0.15} \\
\hline & МATCH & & \\
\hline 7 & SHOULDER JOINT & $4 \mathrm{OL}$ & 0.3 \\
\hline \multirow{2}{*}{8} & NOSE NECK RIB & \multirow{2}{*}{ MNL } & \multirow{2}{*}{0.2} \\
\hline & MEASURE \& CUT & & \\
\hline \multirow{2}{*}{9} & $\begin{array}{l}\text { NOSE NECK RIB } \\
\text { TK WITH }\end{array}$ & \multirow{2}{*}{ SNL } & \multirow{2}{*}{0.32} \\
\hline & BODY & & \\
\hline 10 & $\begin{array}{l}\text { NOSE NECK RIB } \\
\text { JOIN }\end{array}$ & $4 \mathrm{OL}$ & 0.32 \\
\hline 11 & NECK TS & FL & 0.25 \\
\hline \multirow{2}{*}{13} & $\begin{array}{l}\text { PLACKET CLOSE } \\
\& 1 / 16\end{array}$ & \multirow{2}{*}{ SNL } & \multirow{2}{*}{0.32} \\
\hline & UPPER & & \\
\hline \multirow[t]{2}{*}{12} & $\begin{array}{l}\text { PLACKET CLOSE } \\
\& 1 / 16\end{array}$ & SNL & 0.32 \\
\hline & LOWER & & \\
\hline 14 & PLACKET BOX & SNL & 0.4 \\
\hline 15 & NECK PIPING & FB & 0.23 \\
\hline
\end{tabular}




\begin{tabular}{|c|c|c|c|}
\hline \multirow{2}{*}{16} & $\begin{array}{l}\text { MAIN LBL } \\
\text { ATTACH WITH }\end{array}$ & \multirow{2}{*}{ SNL } & \multirow[t]{2}{*}{0.32} \\
\hline & FOLD & & \\
\hline 17 & SLV HEM & FL & 0.33 \\
\hline \multirow{2}{*}{18} & $\begin{array}{l}\text { SLEEVE AND } \\
\text { BODY }\end{array}$ & \multirow{2}{*}{ MNL } & \multirow{2}{*}{0.15} \\
\hline & MATCH & & \\
\hline 19 & SLEEVE JOINT & $4 \mathrm{OL}$ & 0.45 \\
\hline 20 & ARM HOLE T/S & FL & 0.32 \\
\hline 21 & SIDE SEAM & $4 \mathrm{OL}$ & 0.7 \\
\hline \multirow[t]{2}{*}{22} & $\begin{array}{l}\text { SLEEVE CLOSE \& } \\
\text { OPEN }\end{array}$ & \multirow[t]{2}{*}{ SNL } & \multirow[t]{2}{*}{0.37} \\
\hline & TACK & & \\
\hline 22 & BODY HEM & FL & 0.33 \\
\hline 22 & BUTTON HOLE & BH & 0.3 \\
\hline 22 & $\begin{array}{l}\text { BUTTON ATTACH } \\
\text { MARK }\end{array}$ & BS & 0.27 \\
\hline 22 & BUTTON PUSH & MNL & 0.2 \\
\hline \multirow{3}{*}{22} & $\begin{array}{l}\text { FINAL THREAD } \\
\text { CUT }\end{array}$ & \multirow{2}{*}{ MNL* } & \multirow{2}{*}{0.5} \\
\hline & STICKER REMOVE & & \\
\hline & TOTAL & & 8.41 \\
\hline
\end{tabular}

Table 5: Operation Breakdown/Bulletin (OB) of the Tee Shirt with Required Machines

Above factors and methods save 9.87-8.41 = 1.46 minutes Total Save $=1.81+1.46=3.27$ minutes

\begin{tabular}{|c|c|c|c|}
\hline \multirow[t]{2}{*}{$\begin{array}{l}\text { Factors } \\
\text { Influencing } \\
\text { Increasing } \\
\text { Efficiency }\end{array}$} & \multirow[t]{2}{*}{ Impact } & $\begin{array}{l}\text { Factors } \\
\text { Influencing } \\
\text { Negatively } \\
\text { and } \\
\text { Decreasing }\end{array}$ & \multirow[t]{2}{*}{ Weightage } \\
\hline & & Efficiency & \\
\hline $\begin{array}{l}\text { Good } \\
\text { Planning and }\end{array}$ & \multirow[t]{2}{*}{ Direct } & \multirow{2}{*}{$\begin{array}{l}\text { Poor Planning } \\
\text { and } \\
\text { Leadership }\end{array}$} & \multirow[t]{2}{*}{5} \\
\hline Leadership & & & \\
\hline \multirow{2}{*}{ Automation. } & \multirow{2}{*}{ Direct } & Machine & \multirow{2}{*}{5} \\
\hline & & Breakdown & \\
\hline \multirow{2}{*}{ MMR } & \multirow{2}{*}{ Direct } & Change Over & \multirow{2}{*}{5} \\
\hline & & time & \\
\hline \multirow{2}{*}{$\begin{array}{l}\text { Layout to } \\
\text { reduce SMV }\end{array}$} & \multirow{2}{*}{ Direct } & $\begin{array}{l}\text { Operator } \\
\text { Working }\end{array}$ & \multirow{2}{*}{5} \\
\hline & & Skills & \\
\hline
\end{tabular}

* SNL- Single Needle Machine, MNL-Multiple Needle/2Needle machines, FL- Flatlock, OLOverlock, 4OL-4Thread-Overlock

\begin{tabular}{|l|l|l|l|}
\hline $\begin{array}{l}\text { Assign multi-skilled } \\
\text { operators to do multiple } \\
\text { operations }\end{array}$ & Direct & $\begin{array}{l}\text { Working } \\
\text { Experience }\end{array}$ & 5 \\
\hline $\begin{array}{l}\text { Incentive for high } \\
\text { performance to reduce } \\
\text { OT }\end{array}$ & Direct & $\begin{array}{l}\text { Physical } \\
\text { Working } \\
\text { Environme } \\
\text { nt }\end{array}$ & 4 \\
\hline $\begin{array}{l}\text { Reduce and have required } \\
\text { Work In } \\
\text { Process -WIP. }\end{array}$ & Direct & $\begin{array}{l}\text { Supply } \\
\text { Chain } \\
\text { Problem and } \\
\text { Material } \\
\text { Quality }\end{array}$ & 4 \\
\hline $\begin{array}{l}\text { Reduce or eliminate } \\
\text { Non Productive } \\
\text { Time-NPT. }\end{array}$ & $\begin{array}{l}\text { Indirec } \\
\mathrm{t}\end{array}$ & $\begin{array}{l}\text { Job } \\
\text { satisfacti } \\
\text { on }\end{array}$ & 3 \\
\hline $\begin{array}{l}\text { Operators' skill development } \\
\text { through Indirec } \\
\text { training. }\end{array}$ & $\begin{array}{l}\text { Training } \\
\text { and } \\
\text { Developme } \\
\text { nt }\end{array}$ & 3 \\
\hline $\begin{array}{l}\text { Right first } \\
\text { time quality- no rework. }\end{array}$ & $\begin{array}{l}\text { Indirec } \\
\text { t wise }\end{array}$ & $\begin{array}{l}\text { Assigned } \\
\text { Qual } \\
\text { ity } \\
\text { Targ } \\
\text { ets }\end{array}$ & 3 \\
\hline $\begin{array}{l}\text { PO wise output. } \\
\text { batch wise } \\
\text { size }\end{array}$ & $\mathrm{t}$ & $\begin{array}{l}\text { Imbalance } \\
\mathrm{d} \text { input }\end{array}$ & 3 \\
\hline
\end{tabular}

Table 6: Summarising the factors 


\begin{tabular}{|l|l|l|}
\hline Factor & Actions & Savings \\
\hline $\begin{array}{l}\text { Good } \\
\text { Planning and } \\
\text { Leadership }\end{array}$ & $\begin{array}{l}\text { PO Wise input } \\
\text { Cutting Savings }\end{array}$ & $\begin{array}{l}\text { Fabric which is } \\
60 \% \text { of the total } \\
\text { cost }\end{array}$ \\
\hline Automation & Reduce SMV & $\begin{array}{l}\text { Cost of work } \\
\text { hour }\end{array}$ \\
\hline MMR & Reduce Manpower & Cost of Labour \\
\hline Layout & $\begin{array}{l}\text { Reduce WIP } \\
\text { Reduce SMV } \\
\text { Reduce Men }\end{array}$ & Cost of Labour \\
\hline $\begin{array}{l}\text { Assign } \\
\text { Operators }\end{array}$ & $\begin{array}{l}\text { Reduce Manpower } \\
\text { Reduce machine }\end{array}$ & Labour Cost \\
\hline Reduce OT & Reduce Work hour & Labour Cost \\
\hline
\end{tabular}

Table 7: Summary of Factors

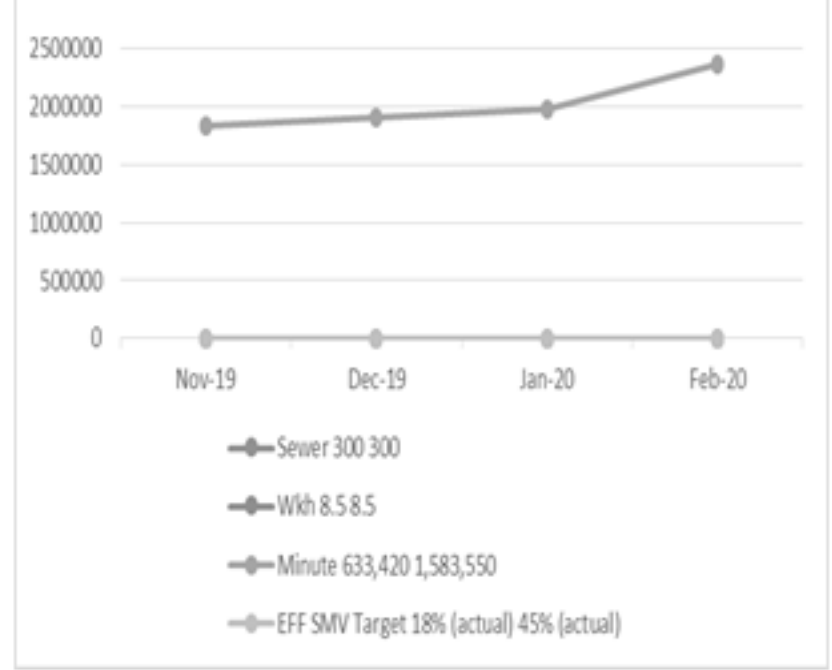

Fig 10: the climb of efficiency graph

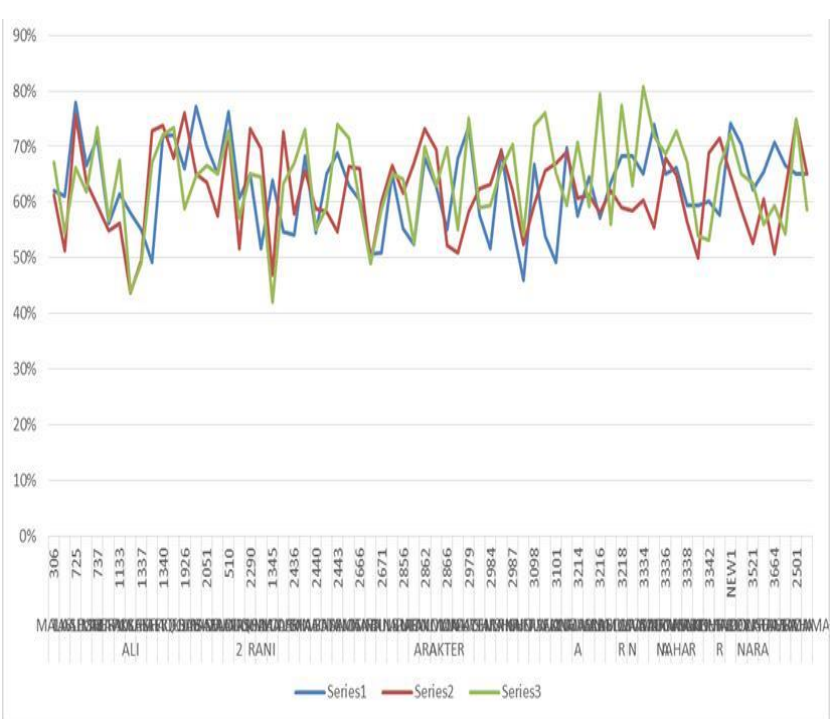

Fig 11: last 3 months skill overlapping

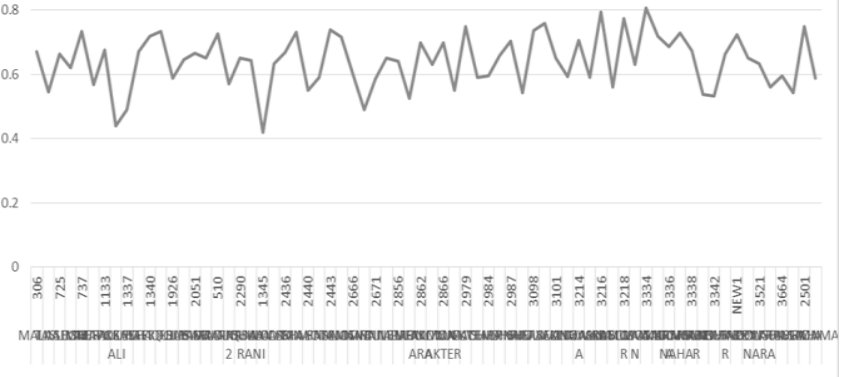

Fig 12: Last month



Fig 13: Efficiency

Efficiency (X) is increasing while Cost of manufacturing

(A) is decreasing and Revenue Earnings increasing (Y)

\begin{tabular}{|c|c|c|}
\hline Efficiency & Cost \$ & Revenue \\
\hline $45 \%$ & 3 & 0.15 \\
\hline $50 \%$ & 2.7 & 1.215 \\
\hline $65 \%$ & 2.076923 & 6.813346 \\
\hline
\end{tabular}

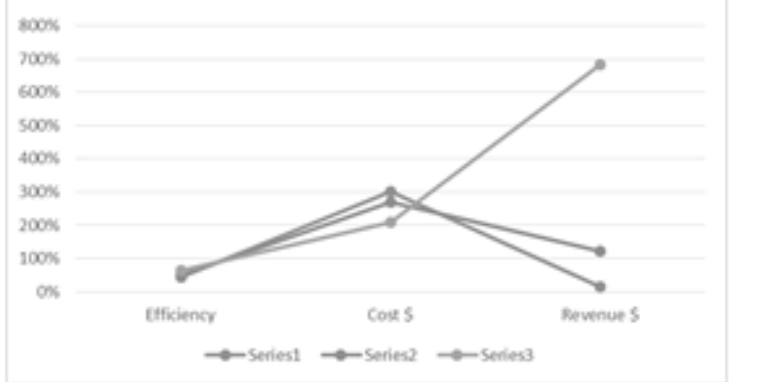

7. Discussion and Analysis

Explanation of the rationale for Statistical Analysis used in the study

Model Summary ${ }^{b}$ 


\begin{tabular}{|c|c|c|c|c|c|}
\hline \multirow{2}{*}{$\begin{array}{l}\text { Mode } \\
\text { l }\end{array}$} & \multirow{2}{*}{$\mathbf{R}$} & $\mathbf{R}$ & Adjuste & $\begin{array}{l}\text { Std. } \\
\text { Error }\end{array}$ & \multirow{2}{*}{$\begin{array}{l}\text { Durbin } \\
\text { Watson }\end{array}$} \\
\hline & & Square & $\begin{array}{l}\text { d R } \\
\text { Square }\end{array}$ & $\begin{array}{l}\text { of the } \\
\text { Estimate }\end{array}$ & \\
\hline 1 & $.591^{\mathrm{a}}$ & 0.349 & 0.343 & $7.09 \%$ & 1.298 \\
\hline
\end{tabular}

a. Predictors: (Constant), Manufacturing Cost, Revenue

b. Dependent Variable: Efficiency

ANOVA $^{a}$

\begin{tabular}{|l|c|c|l|l|}
\hline Model & $\begin{array}{l}\text { Sum of } \\
\text { Squares }\end{array}$ & df & $\begin{array}{l}\text { Mean } \\
\text { Square }\end{array}$ & F \\
\hline Regression & 5570.071 & 2 & 2785.036 & 55.465 \\
\hline 1Residual & 10394.071 & 207 & 50.213 & \\
\hline Total & 15964.142 & 209 & & \\
\hline
\end{tabular}

a. Dependent Variable: Efficiency

b. Predictors: (Constant), Manufacturing cost, Revenue

\section{Coefficients $^{\mathrm{a}}$}

\begin{tabular}{|c|c|c|c|c|c|c|}
\hline & & & $\begin{array}{l}\text { Standardiz } \\
\text { ed }\end{array}$ & & \\
\hline & & & & $\begin{array}{l}\text { Coefficient } \\
s\end{array}$ & & \\
\hline & & \multicolumn{2}{|c|}{$\begin{array}{l}\text { Unstandardize } \\
\text { d Coefficients }\end{array}$} & & & \\
\hline & & & & & & Sig \\
\hline \multicolumn{2}{|c|}{ Model } & & Std. & & t & . \\
\hline & & B & Error & Beta & & \\
\hline \multirow[t]{2}{*}{1} & (Constant) & 45.267 & 0.872 & & 51.9 & 0 \\
\hline & & & & & 0 & 0 \\
\hline & Revenue & 1.166 & 0 & 1.55 & 10.51 & 0 \\
\hline & & E-006 & & & 4 & 0 \\
\hline & Manufacturinge & - & 0 & -1.399 & - & 0 \\
\hline & ost & 1.763 & & & 9.489 & 0 \\
\hline & & E-006 & & & & \\
\hline
\end{tabular}

\section{Collinearity Statistics}

\begin{tabular}{|r|l|l|l|}
\hline \multicolumn{2}{|l|}{$\begin{array}{l}\text { 95.0\% Confidence Interval } \\
\text { for B }\end{array}$} & \multicolumn{3}{|l|}{ Collinearity Statistics } \\
\hline $\begin{array}{l}\text { Lower } \\
\text { Bound }\end{array}$ & $\begin{array}{l}\text { Upper } \\
\text { Bound }\end{array}$ & Tolerance & \multicolumn{2}{l|}{ VIF } \\
\hline 43.547 & 46.986 & & \\
\hline 0 & 0 & 0.145 & 6.913 \\
\hline 0 & 0 & 0.145 & 6.913 \\
\hline
\end{tabular}

\section{Residuals Statistics ${ }^{\mathrm{a}}$}

\begin{tabular}{|c|c|c|c|c|c|}
\hline & \multirow{2}{*}{$\begin{array}{l}\text { Minimu } \\
\text { m }\end{array}$} & \multirow{2}{*}{$\begin{array}{l}\text { Maximu } \\
\text { m }\end{array}$} & \multirow[b]{2}{*}{ Mean } & Std. & \multirow[b]{2}{*}{$\mathbf{N}$} \\
\hline & & & & $\begin{array}{l}\text { Deviatio } \\
\text { n }\end{array}$ & \\
\hline $\begin{array}{l}\text { Predict } \\
\text { e }\end{array}$ & \multirow[t]{2}{*}{$24.35 \%$} & \multirow[t]{2}{*}{$66.63 \%$} & \multirow{2}{*}{$\begin{array}{r}45.64 \\
\%\end{array}$} & \multirow[t]{2}{*}{$5.16 \%$} & $\begin{array}{l}2 \\
1\end{array}$ \\
\hline d Value & & & & & 0 \\
\hline \multirow{2}{*}{$\begin{array}{l}\text { Residu } \\
\text { al }\end{array}$} & - & \multirow{2}{*}{$15.66 \%$} & - & \multirow{2}{*}{$7.05 \%$} & 2 \\
\hline & $22.58 \%$ & & $0.00 \%$ & & $\begin{array}{l}1 \\
0\end{array}$ \\
\hline \multicolumn{6}{|l|}{ Std. } \\
\hline $\begin{array}{l}\text { Predict } \\
\text { e }\end{array}$ & -4.123 & 4.067 & 0 & 1 & $\begin{array}{l}2 \\
1 \\
0\end{array}$ \\
\hline \multicolumn{6}{|l|}{ d Value } \\
\hline Std. & \multirow[b]{2}{*}{-3.187} & \multirow[b]{2}{*}{2.21} & \multirow[b]{2}{*}{0} & \multirow[b]{2}{*}{0.995} & 2 \\
\hline $\begin{array}{l}\text { Residu } \\
\text { al }\end{array}$ & & & & & $\begin{array}{l}1 \\
0\end{array}$ \\
\hline
\end{tabular}

\section{a. Dependent Variable: Efficiency}

The adjusted R2 value was at 0.343 . This indicated that $34.3 \%$ of the variations in Efficiency (E) could be explained by the predictor variables of Revenue (R) and Manufacturing Cost (MC). The adjusted R2 value is too low because the other factors should not be considered in this study.

The regression equation was found to be robust with rejection of the null hypotheses. None of the equation was found to suffer from the problems of autocorrelation and multicillinearity as has been evident from the Durbin- Watson statistic lying between 1.20 and 2.10 and the VIF for the predictor variables were around 10.00 .

A synopsis of the dependent variable and the concerned statistically significant predictor variables is given below: 


\begin{tabular}{|l|l|l|}
\hline \multirow{2}{*}{$\begin{array}{l}\text { Dependent } \\
\text { Variable }\end{array}$} & \multicolumn{2}{|l|}{ Predictor Variables } \\
\cline { 2 - 3 } & Revenue (R) & $\begin{array}{l}\text { Manufacturing Cost } \\
\text { (C) }\end{array}$ \\
\hline Efficiency (E) & $\checkmark$ & $\checkmark$ \\
\hline
\end{tabular}

It has been observed that Efficiency (E) influences by Revenue (R) and Manufacturing Cost (MC). It has been found that Revenue $(R)$ is positively correlated with Efficiency (E) which indicating that if the efficiency of the readymade garments factories increased the revenue also been raised. It has also been seen that the Manufacturing Cost (MC) is negatively correlated with Efficiency (E) which revealed that if the efficiency of the readymade garments factories grown up the cost was ultimately decreased.

The distribution of the residuals of the regression equation is given below which represents that though the adjusted $\mathrm{R} 2$ are low, still the regression equation is or less robust.
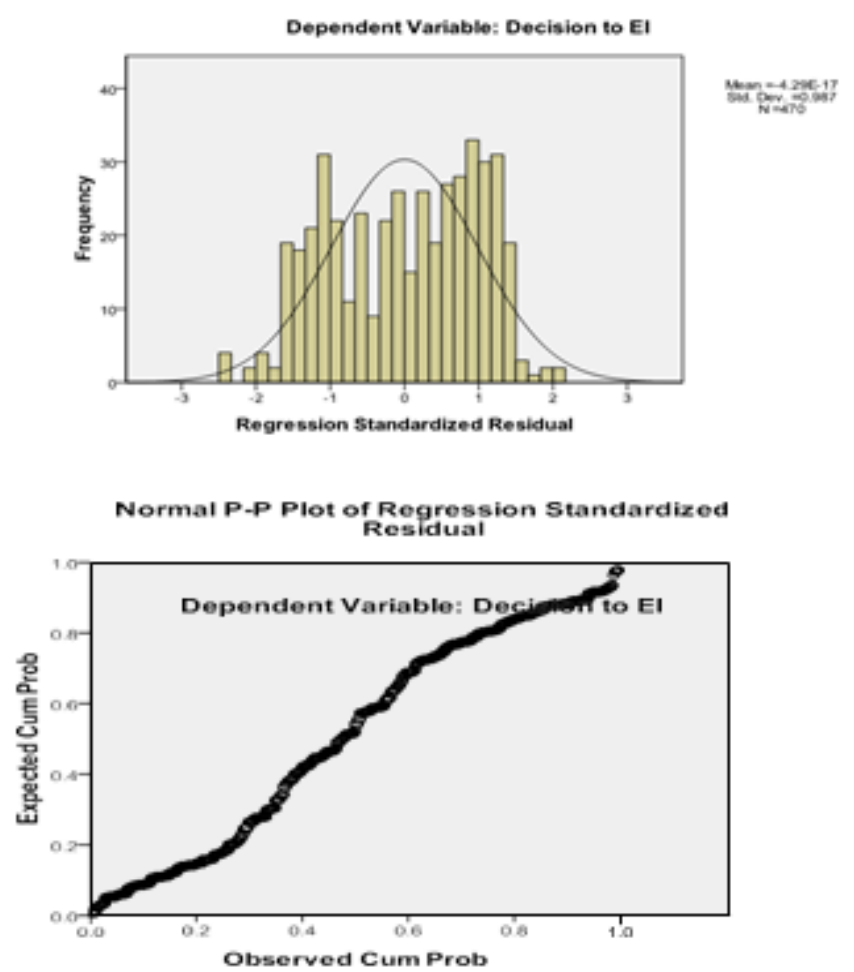

\section{Conclusion}

The efficiency is the most important performance indicator of any industry especially in the readymade garments industry which helps to make revenue grow. An efficient garments industry increases the productivity and as a result the earnings rise. From the study it can be concluded that the efficiency is positively correlated with revenue and negatively related with manufacturing cost. Finally it may be said that if the efficiency of the readymade garments industry in Bangladesh increases as the productivity grows and the revenue rises, too but the manufacturing cost decreases. The factors be considered for increasing the efficiency are: good leadership, automation, assigning multiskilled operations, incentive for high performance to reduce OT, right first time quality-no rework, PO wise batch wise size wise output, reduced and have only required work in progress, reduce or eliminate non-productive time are confirmed by the study.

\section{References}

[1.] Ahmed, F.E., 2004. The rise of the Bangladesh garment industry: Globalization, women workers, and voice. NWSA journal, pp.34-45.

[2.] Akter, S., 2016. Leadership and Organisational factors for creating Sustainable Readymade garment (RMG) sector in Bangladesh.

[3.] Alam, F.B. and Hasan, M.M. 2018. Analysis on SMV to Increase Productivity in Sewing Section: A Case Study on T-Shirt Manufacturing in Bangladesh. "International Journal of Research in Engineering and Science (IJRES), vol. 06, no. 08, 2018, pp. 18-24

[4.] Alam, M.S., Selvanathan, E.A., Selvanathan, S. and Hossain, M., 2019. The apparel industry in the post multifiber arrangement environment: A review. Review of Development Economics, 23(1), pp.454-474.

[5.] Alauddin, M., 2018. Process improvement in sewing section of a garments factory a case study.

[6.] Collins, P. and Glendinning, S., 2004. Production planning in the clothing industry: failing to plan is planning to fail. Control, 1, pp.16-20.

[7.] Chowdhury, Dilruba Shoma, 2017. Women's Rights and Voice in the ReadyMade Garments Sector of Bangladesh: Evidence from Theory and Practice. Journal of International Women's Studies, 18(2), 118-133. Available at: http://vc.bridgew.edu/jiws/vol18/iss2/8 
[8.] Dailey, K.W., Wieckhorst, D. and Welch, B., 2003. Lean manufacturing pocket handbook. Published Company.DW Publishing Company.

[9.] David, Birnbaum, 2017. A Tale of Three Countries - Bangladesh, India and Vietnam, https://www.juststyle.com/comment/a-tale-of-threecountries-vietnam- indiabangladesh_id131188.aspx

[10.] Faizur, Mohammad, Lal Mohan, and Abdul Mannan., 2009. "Quality Management in Garment Industry of Bangladesh". Management of Sustainable Development, $1(2)$.

[11.] Graetz, F. and Smith, A.C., 2010. Managing organizational change: A philosophies of change approach. Journal of change management, 10(2), pp.135- 154.

[12.] Gupta, S. and Starr, M., 2014. Production and operations management systems. CRC Press.

[13.] [Howlader, M.R., Islam, M.M., Sajib, M.T.H. and Prasad, R.K., 2015. Practically observation of standard Minute Value of Tshirt. International Journal of Engineering and Computer Science, 4(3), pp.1068510689.

[14.] Islam, M.M. and Adnan, A.T.M., 2016. Improving ready- made garment productivity by changing worker attitude. European Scientific Journal, 12(4).

[15.] Jadhav, S.S., Sharma, G.S., Daberao, A.M. and Gulhane, S.S., 2017. Improving Productivity of Garment Industry with Time Study. International Journal on Textile Engineering and Processes, 3(3), pp.1-6.

[16.] Joarder, M.A.M., Hossain, A.K.M. and Hakim, M.M., 2010. Post-MFA performance of Bangladesh apparel sector. International Review of Business Research Papers, 6(4), pp.134-144.

[17.] Kaddar, Taher Rajab, 2019. "Quality Assurance in the Ready-Made Garment Industry." Journal of Textile Science \& Fashion Technology 2, no. 3: 3-5.

[18.] Karacapilidis, Nikos I., and Costas P. Pappis, 1996. "Production Planning and Control in Textile Industry: A Case Study." Computers in Industry 30, no. 2: 127-44.
[19.] Karim, R. 201. 'Impact of Changeover time on productivity: A case study', (06), pp. 46-52.

[20.] Khan, A. G., Moudud, S. and Huq, U. 2019. 'Job Satisfaction of Garments Industry in a Developing Country', 4(2), pp. 115-122.

[21.] Kitaw, D., Matebu, A. and Tadesse, S., 2010. Assembly line balancing using simulation technique in a garment manufacturing firm. Zede Journal, 27, pp.69-80.

[22.] Prasanta, S. (2012) '20 Ways to Improve Productivity in Garment Production', Apparel Production, industrial engineering, p.

http://www.onlineclothingstudy.com/2012/0 2/20-ways.

[23.] Rahman, H., Roy, P.K., Karim, R. and Biswas, P.K., 2014. Effective Way to Estimate the Standard Minute Value (SMV) Of A T-Shirt By Work Study. European Scientific Journal, 10(30).

[24.] Rahman, H. and Amin, A. 2016. 'An Empirical Analysis of the Effective Factors of the Production Efficiency in the Garments Sector of Bangladesh', 3(3), pp. 30-36.

[25.] Rahman, H., Roy, P.K., Karim, R. and Biswas, P.K., 2014. Effective Way to Estimate the Standard Minute Value (SMV) Of A T-Shirt By Work Study. European Scientific Journal, 10(30).

[26.] Rahman, M. H. and Amin, M. Al (2016) 'An Empirical Analysis of the Effective Factors of the Production Efficiency in the Garments Sector of Bangladesh', European Journal of Advances in Engineering and Technology, 3(3), pp. 30-36. Available at: www.ejaet.com.

[27.] Ramesh Babu, V. (2011) Industrial engineering in apparel production, Industrial Engineering in Apparel Production. doi: $10.1533 / 9780857095541$.

[28.] Saha, P. and Mazumder, S., 2015. Impact of working environment on less productivity in RMG industries: A study on Bangladesh RMG sector. Global Journal of Management And Business Research. 
[29.] Sarker, A.K., 2019. Development of a preventive maintenance schedule and evaluation of overall equipment effectiveness in a selected garment factory: a case study.

[30.] Sarkar, P. (no date) 'Garment Maker's Key Performance', OCL.

[31.] Saxena, S. B. and Salze-lozac, V. 2010. 'Competitiveness in the garment and textiles industry: Creating a supportive environment', The Asia Foundation, 1, pp. $1-53$.

[32.] Sudarshan, B., 2016. 'Improving Modular Sewing Line Efficiency through Multi-Skill Labor System', (December 2015).

[33.] da Silva, I.B. and Godinho Filho, M., 2019. Single-minute exchange of die (SMED): a state-of-the-art literature review. The International Journal of Advanced Manufacturing Technology, 102(9-12), pp.4289-4307.

[34.] Sohel Ahmed, M. and Chowdhury, S.I., 2018. Increase the Efficiency and Productivity of Sewing Section through Low Performing Operators Improvement by using Eight Wastes of Lean Methodology. Global Journal of Research In Engineering.

[35.] Stojanov, T., Liu, Y. and Ding, X., 2016. Performance Factor Assessment Method for Projection of General Assembly Line in Garment Manufacture. J Fashion Technol Textile Eng 4: 1. of, 7, p.2.

[36.] Taiichi Ohno'.Nabi, F., Mahmud, R. and Islam, M. 2015. 'Improving Sewing Section Efficiency through Utilization of Worker Capacity by Time Study Technique', 4(1), pp. 1-8. doi: 0.5923/j.textile.20150401.01.

[37.] The Daily Prothom Alo, 2019. Bangladesh is behind Vietnam in the export of garments https://www.prothomalo.com/ 16 Nov 2019.

[38.] Van Aartsengel, A. and Kurtoglu, S., 2013. A guide to continuous improvement transformation: Concepts, processes, implementation. Springer Science \& Business Media.

[39.] Yemane, A., Gebremicheal, G., Meraha, T. \& Hailemicheal, M. 2020. Productivity Improvement through Line Balancing by Using Simulation Modeling (Case study Almeda Garment Factory) Journal of
Optimization in Industrial Engineering. 13 (1), 153-165.

\section{Acknowledgement}

The author acknowledges the fashion brands like: M\&S, Adidas, Puma, Nike's training sessions that enabled the writer to understand machine layout and effectively designing production capitalising maximum efficiency. Also acknowledging the cooperation of OPEX and SINHA Textiles Group for allowing doing the research for a year on the above mentioned subject.

\section{Author Profile}

Mohammad Alam Tareque received Masters in English, HRM, and MDS from National University of Bangladesh. He is a certified lead auditor on health and safety, quality and environment management systems. He is a $\mathrm{PhD}$ candidate in the Bangladesh University of Professionals.

Professor Dr Nazrul Islam recived his PhD from AIT, Thailand, and served as Dean of business Schools in Khulna, North South and Uttara Universities. $\mathrm{He}$ is a renowned member of AMDISA, Asia; and worked as Pro VC of Canadian University of Bangladesh.

Dr Roy received his $\mathrm{PhD}$ from University of Burdwan, India and is an educational consultant. He is also a financial adviser to Opex and Sinha Textiles Group. 